\title{
DETERMINING FACTORS OF FIRM SURVIVABILITY A STUDY OF UNIVERSITY SPIN-OFFS IN INDONESIA
}

\author{
Muhammad Afif Sallatu \\ Faculty of Economics and Business, Universitas Gadjah Mada, Indonesia \\ (afifsallatu@gmail.com) \\ Nurul Indarti \\ Faculty of Economics and Business, Universitas Gadjah Mada, Indonesia \\ (nurulindarti@ugm.ac.id)
}

\begin{abstract}
Nowadays, universities in many countries are encouraged to take their research products to the next level by translating them into commercialized products to benefit society at large. In doing so, they establish a firm, a so-called University Spin-Off (USO), which specializes in carrying out the mission. A USO is a firm which is established to optimize or commercialize the Intellectual Property Rights (IPRs) of the university. Previous studies into USOs, documented in the extant literature, have mainly focused on investigating the initial process of the USOs' establishment, such as the drivers to initiate the USOs. Only a little attention has been paid to investigate the various drivers affecting the development of the USOs. Studies into the survivability of USOs are relatively limited. The current study is intended to fill this gap. Additionally, the findings are expected to add to the existing literature on USOs, particularly in the context of developing countries. This study aims at identifying the factors affecting the USOs' survival. We used the resource-based view and contingency theory to identify and understand the various factors (internal and external) that might affect a USO's survivability. Data for this study were collected through a survey. From the literature, we identified ten relevant factors for a USO's survivability and 41 items to operationalize them, which we then used to develop a questionnaire. The factors are the USO's business orientation, human resources' reputation, product innovation, business plan, business models' innovation, social networks, export activities, capital access, government support, and the business's incubator. The data were collected from 111 USOs established by 14 universities located in five big cities in Indonesia. The survey was conducted from February until May 2017. Before performing the regression analysis, we deployed a factor analysis to validate the instruments and found that all the 41 items were valid and fell into ten component factors. The analysis found that there were only two factors which significantly affected the USO's survivability: Its human resources' reputation and social networks. These findings lead us to a conclusion that building a good reputation and maintaining its social networks are very important to ensure the survivability of a USO.
\end{abstract}

Keywords: determining factors, firm survivability, university spin-off, Indonesia

JEL Classification: M13, O34, O35 


\section{INTRODUCTION}

The high levels of turbulence in most industries are marked by many of the new emerging companies replacing the existing old companies (Caves, 1998; Li and Liu, 2014). Because of this issue, the understanding of how firms can survive and be successful in business for longer has become a central topic of management and organizational reviews (Bonn, 2000). There are at least two fundamental questions attracting the interest of scholars and practitioners, i.e. how a company can survive, and what the determining factors of firm survival are (Bonn, 2000).

In management and organization studies, the term firm survival tends to be associated with organizational performance (Bonn, 2000; Walter, Edelman, \& Hatten, 2014). In this case, the firms that perform well are assumed to have a better chance of survival (Walter et al., 2014). The use of a performance-based approach to understanding firm success and survival has been criticized by Aldrich (1979) and Hannanand Freeman (1989), they argue that comparing firm performance to reveal the chance of success and survival of a firm can be misleading. High-performing firms may have certain features that distinguish them from lowperforming firms, but these features may not automatically be the main reason for the firm's survival (Bonn, 2000). Thus, the high-performance of a firm does not always reflect the level of survival of the firm.

Based on a review of the empirical studies into firms' survival (see Table 1), there are several factors that can be considered as the determining factors for firm survival, such as: Business orientation (Hakala, 2013); product innovation (Cefis \& Marsili, 2006; Löfsten, 2016); human resources' reputation (BerbegalMirabent, Ribeiro-Soriano, \& García, 2015); business planning (Indarti \& Langenberg, 2004; Löfsten, 2016); business models' innovation (Velu, 2015); export activity (Dzhumashev, Mishra, \& Smyth,2016); government support (Sørheim, Widding, Oust, \& Madsen, 2011; Payumo, Arasu, Fauzi, Siregar, \& Noviana, 2014); and business incubators (Schwartz, 2013; Mas-Verdú, Ribeiro-Soriano, \& RoigTierno, 2015). In general, the determining factors of firm survival can be classified into internal and external factors.

Table 1. Number of Relevant Factors of Firm Survival

\begin{tabular}{cll}
\hline No. & \multicolumn{1}{c}{ Factors } & \multicolumn{1}{c}{ Reference } \\
\hline & Internal & \\
1 & Business Orientation & Hakala (2013). \\
2 & Human Resources' Reputation & Berbegal-Mirabent et al. (2015), Nicoló (2015). \\
3 & Product Innovation & Cefis and Marsili (2006), Löfsten (2016). \\
4 & Business Planning & Indarti and Langenberg (2004), Löfsten (2016). \\
5 & Business Model Innovation & Velu (2015). \\
6 & Social Network & Indarti and Langenberg (2004) \\
7 & Export Activity & Dzumashev, Mishra, and Smyth(2016). \\
8 & Capital Access & Furlan and Grandinetti (2014), Indarti and Langenberg (2004). \\
& & \\
9 & External & \\
10 & Bovernment Support & Payumo et al. (2014), Sørheim et al. (2011). \\
\hline
\end{tabular}

Source: Compiled by authors 
Based on the Resource-Based View (RBV), a firm's internal aspects (e.g. resources and capabilities) plays an important role in the firm's survival and sustainability (Barney, 1991; 1995; 2007). The RBV sees a firm as a set of productive resources (Penrose, 1959). When the resources of the firm are valuable, scarce, difficult to imitate, and supported by the organization, the firm will have a sustainable competitive advantage (Barney, 2007). The sustainable competitive advantage of the firm is considered to be an important element for the firm's survival (Barney, 1991).

Nevertheless, using the RBV solely to justify the phenomenon of firm survival is still considered to be incomplete (Burns \& Stalker, 1968). According to Scott (1998), the success of managing an organization does not only depend on the organization's internal aspects, but also the nature of its environment. In other words, organizational success requires the alignment of internal resources and external resources. Thus, there are also external (contingency) factors that need to be considered for the success of a firm, especially in maintaining its existence (Scott, 1998).

Based on the literature on firms' survival, two factors are considered to be the dominant factors affecting firm survival (see Table 1). They are government support (Payumo et al., 2014) and the role of business incubators (Schwartz, 2013; Mas-Verdé et al., 2015). In addition, Indarti and Postma (2013) also argue that firms need to interact with their external environment in order to survive. Therefore, in this study we used the RBV (Barney, 1991, 1995) and contingency theory (Woodward, 1965; Burns \& Stalker, 1968; Lawrence \& Lorsch, 1969) to gain a better understanding when exploring the factors for a firm's survivability, which is the mechanism for firm survival (Naidoo, 2010).
Furthermore, in this study, we focus on University Spin-Offs (USOs), which are characterized as firms that have a high survival rate (O'Shea, Allen, Chevalier, \& Roche, 2005). Data from the Association of University Technology Managers (AUTM) (2001) reported that of the 3,376 USOs that were established in the United States of America between 1980 and 2000,68 percent of them were still operating in 2001. Those numbers had also increased significantly by 2014 (4,688 USOs) (AUTM, 2014). These numbers are even higher than the conventional firm survival rates in the United States and other countries.

Similarly, the study of Nerkar and Shane (2003) at the Massachusetts Institute of Technology (MIT) found that USOs have a high level of survival because of their development of radical technology and the wide range of their patents. Both technology and patents are sources of competitive advantage for the firms, which increases the probability of their survival (Löfsten, 2016). Based on these facts, we conclude that the survival level of firms is higher in the context of USOs than in conventional firms.

In general, USO is defined as new, small, and high-tech company that is built in order to optimize the intellectual property of the university (Callan, 2001). Moreover, Pirnay, Surlemont, and Nlemvo (2003) describe the USO as the type of firm that is formed through a spin-off process with the intention to exploit the knowledge, technology, or research products of a university, through a commercialization process. The USO may also be referred to as an entrepreneurial approach that developed within a university (Berbegal-Mirabent et al., 2015).

Furthermore, a USO is basically similar to the other types of firms. For example, a USO can engage in manufacturing industries, Small and Medium-sized Enterprises (SMEs), and be 
included as a new company (Callan, 2001). Nevertheless, the USO retains its own characteristics, which are based on the intellectual property of a university (Pirnay et al., 2003). Thus, it is not appropriate if the USO is entirely equated with the other common types of firms. The uniqueness of the USO calls for an empirical study to explore the phenomenon (Löfsten, 2016).

In addition, although a USO is considered to have a high level of survival (O'Shea et al., 2005), Smith, Chapman, Wood, Barnes, and Romeo (2014) argue that the USO needs to be seen as a phenomenon that can not be generalized. This is indicated through the many studies that have tried to capture the phenomenon of USOs in different contexts (Kroll \& Liefner, 2008; Smith et al., 2014). One of the contextual factors that influence the differences of USOs is the distinction characteristic between developed and developing countries (So, Sampat, Rai, Cook-Deegan, Reichman,Weissman, \& Kapczynski, 2008). Unlike developed countries, the lack of innovation, infrastructure, and poor legal systems that are common in developing countries are considered to have an effect on the USOs' characteristics (Kroll \& Liefner, 2008; Payumo et al., 2014). For example, USOs in developed countries are identified with high-tech companies (Gübeli and Doloreux, 2005); but in developing countries, USOs are mostly established through a low-tech product (Kroll \& Liefner, 2008), or based on natural resources (Payumo et al., 2014). Therefore, in order to generate a clear understanding, the high rate of survival of USOs also needs to be investigated, particularly in the context of the country and its respective regions (Botelho \& Almaida, 2011; Gilsing, Burg, \& Romme, 2010).

Based on the above-mentioned discussion, this current study is intended to identify the determining factors of USO survivability in Indonesia. The main objective of the study is to fill two gaps in the current literature. First, as a relatively new research area, the vast majority of research into USOs is directed at identifying the factors that lead to the formation of USOs by the universities (O'Shea, Rory, Chugh, Harveen, Allen, Thomas, 2008; Sørheim et al., 2011; Berbegal-Mirabent et al., 2015). Even though some studies have reported that the survival rate of USOs is very high (O'Shea et al., 2008), unfortunately studies into USOs that focus on their post-formation aspects are still very limited (Löfsten, 2016).

Second, most studies into firm survivability have been conducted in the context of manufacturing firms, SMEs, and new or young firms (Bonn, 2000; Parry, Jones, Rowley, \& Kupiec-Teahan, 2012; Nicolò, 2015). Similar studies in the context of USOs are rare (Kroll \& Liefner, 2008; Payumo et al., 2014). In addition, many studies into USOs have been conducted in developed countries such as Britain, America, and Europe, while there are very few in developing countries (Kroll \& Liefner, 2008; Payumo et al., 2014). Therefore, this current study is intended to fill these gaps.

\section{LITERATURE REVIEW}

\section{Firm Survival}

In the literature of strategic management and organizational studies, there are at least three variables that have been extensively used to measure the outcome of an organization, e.g. its performance, success, and survival. However, according to Stafford et al. (2010), the variables of firm survival and success are considered to differ from those of firm performance. Firm survival is not a sub-unit of firm success (Stafford et al., 2010), which means the underlying factors of firm performance and success may not automatically also become the 
determinant factors of firm survival (Bonn, 2000). Therefore, the variable of firm survival needs to be classified as a different variable from the other outcomes.

The study of firm survival basically began with the evolutionary theory by Charles Darwin, which explained the term survivability from the perspective of biological science. Furthermore, Hannan and Freeman (1977) and Aldrich (1979) borrowed this evolutionary theory by incorporating it into organizational studies, by adopting the survival discourses. The development of the theory is known as the evolutionary theory of the firm. Firm survivability is defined as the ability of a firm to survive (Naidoo, 2010).

Most literature on firm survival lays more emphasis on the specific perspectives ${ }^{1}$ that researchers use to understand how a firm can survive (Bonn, 2000; Parry et al., 2012; Velu, 2015; Dzhumashev et al., 2016). For example, Cefis and Marsili (2006) and Löfsten (2016) used an innovation perspective to explain how a firm can survive. Alternatively, Mas-Verdú et al. (2015) used the perspective of business incubators to explain firm survival. Following those ideas, in this study we combined two perspectives: The Resource-Based Theory (RBT) and the Contingency Theory (CT) to understand a firm's survivability, which will be explained in the next section. The RBT places more emphasis on the role of internal resources for USOs' survivability, meanwhile the CT focuses more on the role of external resources.

\section{Resource-based View on Firm Survivability}

From the literature on strategic management, the RBT has emerged as an effort to understand a firm's competitiveness from an internal perspective (e.g. resources and capabilities)

\footnotetext{
${ }^{1}$ Perspective is interpreted as the constituent elements that are framed to explain firm survival.
}

(Wernerfelt, 1984; Barney, 1991, 2007). The main focus of the RBT is on how a firm can build a competitive advantage by exploiting its resources (Barney, 1991, 1995). In this case, a firm's resources are defined as all the assets, capabilities, processes, organization, corporate attributes, information and knowledge of the firm (Barney, 1991, 2007).

The RBT has its roots in three basic theories that are derived from both economic and noneconomic disciplines (Barney, 2007). They are the distinctive competency theory (Selznick, 1957), Ricardian economics (Ricardo, 1817), and the theory of the firm growth (Penrose, 1959). Furthermore, the RBT lies on two main assumptions (Barney, 2007). First, firms are assumed to be a collection of productive resources, where they have a diverse collection of productive resources (Penrose, 1959). Second, it is assumed that some existing resources of firms are very difficult to imitate. These two assumptions are known as resource heterogeneity and immobility.

The RBT sees a firm as a set of unique resources and capabilities (idiosyncrasies), where the main task of the firm is to maximize its value through the optimalization of its resources and capabilities (Amit \& Schoemaker, 1993). Resources are considered as an important part and can become the basis for the firm to build its strategic formulation (Wernerfelt, 1984; Grant, 1991).

Through RBT, every firm outcome, such as high performance and survival, are believed to be the output of the firm's resources and capabilities (Esteve-Pérez \& Mañez-Castillejo, 2008), through the development of the firm's competitive advantage (Barney, 2007). This belief is based on the emphasis by RBT on the internal aspects of firms, which are their resources and capabilities. In this case, resources are seen as something owned or controlled by a 
firm (Amit \& Schoemaker, 1993). Therefore, in RBT, firm survivability can be established when the firm has the necessary resources and capabilities (Esteve-Perez \& Manez-Castillejo, 2008).

\section{Contingency Theory on Firm Survivability}

At the end of 1950, the theory of organizational structure was dominated by the classical schools of thought (Taylor, 1911). In this case, it is seen that there is one best way to manage all the different types of organizations. In the 1960s, a new approach called the contingency theory emerged, which argued that achieving an organization's best performance depends on several external factors, rather than the internal structure of the organization (Burns \& Stalker, 1968). The contingency theory pays attention to the impact of environmental factors on the effectiveness of organizational structures and strategies, in order to achieve optimal performance (Woodward, 1965; Lawrence \& Lorsch, 1969).

The history of the contingency theory begins with the studies conducted by Burns and Stalker (1968),Woodward (1965), and Lawrence and Lorsch (1969). In general, they analyzed the relationship between the organizational structure and the environmental conditions encountered (Gudono, 2014). Based on Burns and Stalker in Management of Innovation (1968), there are two types of organizational structures, namely mechanistic and organic. In the contingency theory, it is argued that in order to achieve optimal performance, there are a number of external factors (contingencies) that need to be considered (Burns \& Stalker, 1968). For example, organic structures can only produce optimum performance when they are applied in firms that face highly dynamic environments. Meanwhile, mechanistic structures can only produce optimum performance when applied in firms that face a static environment.

The influence of environmental perspectives in organizational analysis begin with the emergence of a systems approach (Scott, 1998). The system approach is built on the idea that organizations are essentially similar to organisms, that they are open to the influence of their surrounding environment (Scott, 2001). In this case, the organization is regarded as an open system which consists of several interrelated sub-systems (Scott, 1998). The contingency theory also has the ultimate goal of survival or growth (Woodward, 1965). Adopting ideas from the concept of biological science (Darwinism), the organization's ultimate goal can only be achieved when there is a fit between the organization and its environment (Donaldson, 1995).

In its development, the elaboration of the contingency theory's foundation is complemented by Lawrence and Lorsch in their book Organization and Environment (1967). Lawrence and Lorsch (1969) constructed the theory of contingencies based on two basic principles. First, different types of organizations are needed to address different types of markets and technological conditions. Second, organizations which operating in uncertain and unstable environments need more internal differentiation than organizations that operating in less complex and more stable environments (Gudono, 2014).

Furthermore, Lawrence and Lorsch (1969) also argue that an organization's management style needs to vary amongst its sub-organizations, according to their sub-environmental characteristics. For example, the production department usually faces a very clear environment as well as a short time horizon. Therefore, the production department can adopt more formal and bureaucratic ways for personal 
interaction than the marketing department (Gudono, 2014). In other words, an organization can fail to adapt to its environment if the organization fails to choose the appropriate way to fit with the environment (Lawrence \& Lorsch, 1969). The contingency theory's emphasis is on decision-making that can minimize the risks for the organization (Jarvis, 1990).

In this study, the contingency theory is used as a complementary theory - for RBT - in capturing the phenomena of USO survivability in Indonesia. Specifically, it relates to the way external factors contribute to the USOs' survivability in Indonesia. The emphasis of the contingency theory on the external environmental factors plays an important role, and is believed to provide a more comprehensive understanding about the phenomenon of USO survivability in Indonesia.

\section{The Underlying Factors of USO Survivability}

Based on the literature reviews, there are ten variables that are considered to be the underlying factors for USO survivability, which contain eight factors from the USOs' internal aspects and two factors from their external aspects. Each of these underlying factors are derived from a number of literature reviews on two main research topics: Firm survival and USOs. In this study, all the factors are assessed to identify which factors are the determining factors for USO survivability in Indonesia. A discussion of each of the proposed factors is further elaborated in more detail below.

\subsection{Business Orientation}

In general, business orientation is defined as a strategic orientation that represents the main characteristics of an organization (Miller, 1983; Covin and Slevin, 1989). These characteristics include risk taking, proactive and innovative actions (Hakala, 2013). So far, the business orientation of a firm has received a great deal of attention from researchers because it has a strong relationship with firm performance, even in varying and different contexts. Therefore, it is relevant to test business orientation further on other outcome variables, which in this research is the USOs' survivability.

Furthermore, of the three types of characteristics in business orientation, risk taking is considered as the most relevant resource in regard to firm survivability (Aspelund et al., 2005). This is because the risk-taking characteristic reflects the strong entrepreneurial experience of firms' leaders, as the leaders are the key representatives of a firm's characteristics (Aspelund et al., 2005). The importance of the entrepreneurial experience for firms' survivability is because entrepreneurial experience indicates that leaders have faced similar challenges before (Aspelund et al., 2005).

For dynamic business realities, Gersick (1991) argues that the choice between making a change, and persisting with what is, can be less precise when the leaders have less experience of entrepreneurship. This is because the entrepreneurial experience helps leaders interpret the difficulty level of the obstacles arising from their business activities. In other words, the entrepreneurial experience of leaders can minimize the dilemmatic conditions (Aspelund et al., 2005). Therefore, this study focuses on the risk taking characteristic as a characteristic of business orientation when identifying the underlying factors of the USOs' survivability.

\subsection{Human Resource Reputation}

So far, the USO literature has emphasized the importance of the quality of the human resources of firms in supporting their development process (Berbegal-Mirabent et al., 2015). USOs' development can be restrained because of the 
low quality of the available human resources (Berbegal-Mirabent et al., 2015). Thus, the availability of qualified human resources is considered to strenghten the development process of USOs (O'Shea et al., 2005). Nevertheless, USO studies which focus on the issue of qualified human resources, are often conducted to discover the USOs' development process (Franklin, Lockett, \& Wright, 2001; Berbegal-Mirabent et al., 2015), even though the quality of human resources is also considered to affect the survivability of the firms (Lee, 2001; Nutt, 2004), not least the USOs.

Continuing the discussion, Nicolò (2015) argues that a business's reputation allows it to survive. This argument is based on the notion that the reputation of a business is a prerequisite to creating strong, long-term trust with its consumers and other stakeholders. In addition, the business's reputation can also enhance the USO's ability to create value. While it is true that reputable companies can fail, the lack of a reputation is also believed to decrease the chance of survival of a firm (Nicolò, 2015). If the firm has a positive reputation, the business risk is perceived to be low (Goyal \& Yadav, 2014). Building a positive business reputation requires the company to have the ability to meet the expectations of its consumers and other stakeholders (Pfeffer \& Salancik, 1978). In addition, the reputation of the business also has a positive effect on its costs and corporate earnings (Nicolò, 2015). In short, a business's reputation is an important factor for its survival.

Interestingly, Nicolò (2015) argues that the most obvious reflection of a firm's reputation is represented by the quality of its human resources. Based on that, reputation issues are also important to the USOs. In this case, a USO may be perceived as having a good reputation because it is created by a university or public research institution (Callan, 2001; Lockett \&
Wright, 2005, Wright, Binks, Lockett, \& Clarysse, 2005), which has a good reputation in terms of the quality of its human resources. Thus, there is also an urgency and relevancy to examine the effect of the human resources' reputation on the USO's survivability, as one possible determining factor.

\subsection{Product Innovation}

Innovation has an important role in shaping the survivability of a firm. Not only for the new firms, but also for old established firms (Cefis \& Marsili, 2006). With innovation, firms are able to increase their survival chances, by providing a successful niche strategy (Cefis \& Marsili, 2006). Therefore, the study of firm survival tends to be associated with innovation factors (Löfsten, 2016), with no exception made for the USOs.

One of the most obvious forms of innovation for an enterprises's development is its product innovation (Löfsten, 2016). In general, product innovation is defined as a gradual adjustment of the existing products (Nelson \& Winter, 1985). Product innovation shows a relatively small change in the product and optimizes the potential of the product's design (Slater et al., 2014). Many empirical studies find that there is a positive relation between product innovation and firm survival (Perez et al., 2004; Cefis \& Marsili, 2006; Mas-Verdú et al., 2015; Löfsten, 2016). According to that, this study also examines the role of product innovation on the survivability of the USOs.

\subsection{Business Planning}

So far, business planning is considered to improve the competitive ability and survivability of firms (Löfsten, 2016). Business planning is related to the development orientation of the firms (Indarti \& Langenberg, 2004). McMahon (2001), in his study, found that better corporate development orientation is significantly 
associated with better business growth. In addition, good business planning can also enhance a firm's reputation, which further increases the probability of firm survival (Nicolò, 2015). The better a USO's business plan is, the probability of its survival will be higher (Löfsten, 2016). Thus, this study also includes business planning as one of the relevant underlying factors for USO survivability.

\subsection{Business Model Innovation}

Recently, there is increased attention paid to business model innovation by managers, in order to create a competitive advantage and achieve higher performance by their companies (Calia et al., 2007). In contrast to product innovation, business model innovation involves more systemic changes, as it includes changes in value propositions, value creation, and consumer value (Velu \& Stiles, 2013). The study of International Business Machines (IBM) (2008) shows that a firm with higher growth in its operating profits than its competitors emphasizes the importance of business model innovation. The implication, many researchers then suggested, was to test the role of business model innovation even further, to see how it impacts on the survival of the company (Velu, 2015).

The business model is a structural framework that describes a company's system, which consists of a set of synergistic corporate activities, in order to create and capturing value (Zott \& Amit, 2001). In other words, a business model can be seen as a part of corporate strategy, and is a combination of complementary resources to support the commercialization of the company's core products (Vidal \& Mitchell, 2013). Based on this, business model innovation is considered to have an effect on the survivability of a company (Velu, 2015).

\subsection{Social Network}

So far in entrepreneurship studies, there is a general agreement that in order to survive, entrepreneurs and new companies need to involve their social networks (Huggins, 2000). A network represents a media outlet for the entrepreneurs to reduce the risks and costs of their business transactions. In addition, a network is also a means to improve access to business ideas, knowledge and capital (Aldrich \& Zimmer, 1986).

A social network consists of a set of formal and informal relationships between the central actor and the other actors in a circle of connections (colleagues). In this case, a social network represents the channel that entrepreneurs can use to get access to the opportunities, resources, and legitimacy needed for business initiation, growth, and success (Elfring \& Hulsink, 2003; Kristiansen, 2003). Moreover, a social network is considered to be an important factor for the survival of a firm, not least for a USO. Social networks are relevant and need to be included, because in the USO literature, social networking has not been considered to be a noteworthy aspect (Grandi \& Grimaldi, 2003).

\subsection{Export Activity}

In their study, Bernard et al. (2003) and Melitz (2003) concluded that export activity correlates with firm productivity. Companies that export are reported to be more productive than nonexport companies (Greenway \& Kneller, 2007). Specifically, Kimura and Kiyota (2006) found that exporters had 15 percent higher productivity than non-exporters.

Continuing the discussion, Dzumashev et al. (2016) argues that the high productivity which is generated through export activities can also increase the survival of a firm. This is because, in addition to having a positive impact on the firm's profit, export activities also increase the productivity standards that are needed to survive (Greenway \& Kneller, 2007), for example, by 
forcing inefficient companies to get out of the market. Therefore, it can be concluded that those USOs involved with export activities are considered to have a higher level of survivability than the USOs that are not.

\subsection{Capital Access}

In building and developing a business, there are several potential resources that can be used, i.e. personal savings, loans from family networks, joint savings and credit systems, or the capital and banking institutions (Indarti \& Langenberg, 2004). Based on a study in Indonesia, Indarti and Langenberg (2004) found that access to capital has a positive effect on business success. Therefore, it is interesting to see whether capital access can also have a positive or decisive effect on the survivability of firms, especially the USOs in Indonesia.

The arguments presented above are important and need to be examined, according to Sørheim et al. (2011), which suggests that one of the major challenges for USOs is related to issues with capital. Shane and Cabble (2002) argue that USOs are believed to have limited resources, so require an external source of capital or funding in order to pursue their opportunities. Thus, the ability to obtain funding from financial institutions is an important factor for the USOs' survivability (Wright et al., 2006).

\subsection{Government Support}

One of the successful countries in supporting USO activities is the United States. This success was largely influenced by the encouragement of the Bayh-Dole Act (BDA) policy, established in 1980 by the United States legislature (Lockett et al., 2005). In general, the BDA is a policy dealing with the intellectual property rights that result from research funded by public institutions. The main focus of this policy is to increase the acceleration of new technological developments from universities (Lockett et al.,
2005), by transfering the ownership of intellectual property that results from research funded by the government, to the universities or researchers as the inventors (Aldridge \& Audretsch, 2010; 2011). Based on this, it can be seen that the government also has an important role in the development of the USOs.

Correspondingly, some of the literature emphasizes the importance of government support for the success of USOs in different countries and regions (Franklin et al., 2001; Gübeli \& Doloreux, 2005; Rasmussen, 2011; Furlan \& Grandinetti, 2014), with no exception in Indonesia (Payumo et al., 2014). The high level of uncertainty in the USO business can negatively affect the existence of USOs (Sørheim et al., 2011). Thus, government support becomes central to the existence of USOs (Sørheim et al., 2011).

\subsection{Business Incubators}

Business incubators are believed to directly or indirectly support USOs' activities (Löfsten \& Lindelöf, 2002). In general, business incubators serve to provide training and mentoring to the USOs' actors, in order to expand their businesses (Mas-Verdú et al., 2015). Business incubators may also provide access to the capital institutions (Berbegal-Mirabent et al., 2015) and networks that are useful for the operation and development of the USOs' businesses (Löfsten, 2010). Thus, the support provided by business incubators has become one of the success factors for USOs (Helm\& Mauroner, 2007).

Although the main purpose of business incubators is to create new companies (BerbegalMirabent et al., 2015), several recommendations to examine the role of business incubators in the success and survival of companies exist (Schwartz, 2009). Similarly Schwartz (2013), through various studies, noted that there is an influence by business incubators on the age of 
companies, especially noticeable in those that have existed for more than ten years. Therefore, the importance of the business incubator's role is believed not only to affect the creation and success of a USO, but also its survivability.

\section{METHOD, DATA, AND ANALYSIS}

In general, this research uses a behavioral study as its approach, which is designed as an exploratory research. Cooper and Schindler (2014) stated that the exploratory model is used for relatively new research, where the researcher needs to explore the general picture of what is being research. Furthermore, a quantitative approach was also employed to reveal the determining factors of USO survivability through a series of relevant statistical tests. Thus, in general, this study is a quantitative exploratory research.

\section{Population and Samples}

University-based firms in Indonesia were chosen as the population of this research. Indonesia was selected because of the considerable increase in USO development activities there, but there is still a lack of empirical studies which can be used as references to discuss the phenomenon of USOs in Indonesia (Payumo et al., 2014). A purposive sampling method was employed in this research, with two criteria for the sample. Firstly, the firms that became the object of the research were classified as USOs. According to Callan (2001), Lockett and Wright (2005), and Wright et al. (2005), a firm may be classified as a USO, if it: 1) Owns a license or use the intellectual property of a university or public research institution; 2) owns an investment (equity) from the university or public research institution; 3) is directly established by a university or public research institution. Secondly, the USOs in this study have been founded and operating for at least six months.
The data for this study were collected in five big cities in Indonesia, from Yogyakarta, Jakarta, Bogor, Malang, and Makassar. Specifically, the data were collected from USOs that were linked with 14 universities around the research locations. The locations' selection refered to the concept of a USO as a universitybased firm (Rasmussen, 2011). Moreover, these five locations were selected because there are a number of major universities located in those cities, which were classified in the top 10 university rankings in Indonesia (KEMENRISTEKDIKTI, 2016).

\section{Pilot Study}

The type of data were primary data, collected by a survey method with open and closed questions. The questionnaire in this study was based on the information from a pilot study, in which the indepth interview method was used with one of the relevant and credible USOs to provide preliminary information related to USOs in Indonesia; in this case, PT. Swayasa Prakarsa based at Gadjah Mada University. The pilot study was conducted in order to build a relevant research instrument (questionnaire), in order to capture further information related to the phenomenon of USOs and their survivability in Indonesia.

In general, the in-depth interview was conducted using the semi-structural method. There are six major topics covered by the interview, which are: 1) The pre-formation process of the USO; 2) the post-formation process of the USO; 3 ) the leadership of the USO; 4) the external environment of the USO; 5 ) the perception of survivability of the USO; and 6) the perception of the USO phenomenon in Indonesia. The descriptive part of the questionnaire used was developed based on the information from the pilot study. 


\section{Data Analysis}

In this study, the data were analyzed through two stages of analysis, using two different analytical methods. First, Exploratory Factor Analysis (EFA) was used to investigate the construct patterns that were formed, based on the overall measurement items. This is to see how many constructs were formed from the 41 measurement items of each independent proposed variable, as well as the four measurement items of the dependent variable. Second, a Multiple Regression Analysis (MRA) was used after the EFA, when a number of the antecedent constructs of the USOs' survivability have been obtained. Through the MRA, a number of the antecedents found by the EFA were tested to identify the determining factors for USO survivability in Indonesia. The statistical model of the MRA is:

$$
\begin{aligned}
\mathrm{Y}= & \alpha+\beta 1 \mathrm{X} 1+\beta 2 \mathrm{X} 2+\beta 3 \mathrm{X} 3+\beta 4 \mathrm{X} 4+ \\
& \beta 5 \mathrm{X} 5+\beta 6 \mathrm{X} 6+\beta 7 \mathrm{X} 7+\beta 8 \mathrm{X} 8+ \\
& \beta 9 \mathrm{X} 9+\beta 10 \mathrm{X} 10+\varepsilon
\end{aligned}
$$

\section{RESULT AND DISCUSSION}

\section{Descriptive Statistic}

In general, the majority of the USOs sampled are incorporated companies (35.1percent), and 50.5 percent of the USOs have operated for less than five years. Most of the USOs are located in cities or other urban areas (85.6 percent), and 72.1 percent have the status of a holding company. The majority of the USOs are engaged in the service sector (51.4 percent), and their markets' geographical segmentation is still dominated by their local area (71.2 percent). Finally, the size of USOs sampled are classified as either small (41.4 percent) or medium (25.2 percent) enterprises, while most of the USOs have a net income under fifty million rupiah (63.9 percent). The general information of the USO samples are presented in Table 2.

Table 2. Descriptive Statistic of the USO Samples

\begin{tabular}{ccc}
\hline \multicolumn{1}{c}{ USOs Description } & Frequency & Percentage (\%) \\
\hline $\begin{array}{c}\text { Form of USO } \\
\text { - Incorporated Company }\end{array}$ & 39 & \\
- Sole Propiertorship & 25 & 35.1 \\
- Limited Partnership & 17 & 22.5 \\
- Cooperative & 12 & 15.3 \\
- University Business Unit & 11 & 10.8 \\
- Foundation & 4 & 9.9 \\
- Stated-Owned Enterprise & 2 & 3.6 \\
- Firm & 1 & 1.8 \\
$\quad$ Total & $\mathbf{1 1 1}$ & 0.9 \\
Age of USO & & $\mathbf{1 0 0}$ \\
- $\quad$ 5 Years & 56 & \\
- >5 Years & 55 & 50.5 \\
$\quad$ Total & $\mathbf{1 1 1}$ & 49.5 \\
Location of USO & & $\mathbf{1 0 0}$ \\
- City/Urban & 95 & \\
- Sub-Urban & 13 & 85.6 \\
- Rural & 3 & 11.7 \\
$\quad$ Total & $\mathbf{1 1 1}$ & $\mathbf{1 0 0}$ \\
\hline
\end{tabular}




\begin{tabular}{|c|c|c|}
\hline \multicolumn{3}{|l|}{ Status of USO } \\
\hline - Holding Company & 80 & 72.1 \\
\hline - Branch Company & 4 & 3.6 \\
\hline \multirow{2}{*}{$\begin{array}{l}\text { - Subsidiary Company } \\
\text { Total }\end{array}$} & 27 & 24.3 \\
\hline & 111 & 100 \\
\hline \multicolumn{3}{|l|}{ Industry of USO } \\
\hline - Manufacturing & 15 & 13.5 \\
\hline - $\quad$ Services & 57 & 51.4 \\
\hline - Banking & 5 & 4.5 \\
\hline - Retail & 19 & 17.1 \\
\hline - Creative Industry & 4 & 3.6 \\
\hline \multirow{2}{*}{$\begin{array}{l}\text { - Agribusiness } \\
\text { Total }\end{array}$} & 11 & 9.9 \\
\hline & 111 & 100 \\
\hline \multicolumn{3}{|c|}{$\begin{array}{l}\text { Market Segmentation of USO (more than one option } \\
\text { are possible) }\end{array}$} \\
\hline - Local & 79 & 71.2 \\
\hline - Domestic/National & 52 & 46.8 \\
\hline - International & 9 & 8.1 \\
\hline - University Area & 4 & 3.6 \\
\hline \multicolumn{3}{|l|}{ Size of USO (based on labor) } \\
\hline - $\operatorname{Big}(\leq 100)$ & 6 & 5.4 \\
\hline - $\quad$ Medium $(20-99)$ & 28 & 25.2 \\
\hline - $\quad$ Small $(5-19)$ & 46 & 41.4 \\
\hline \multirow{3}{*}{\multicolumn{3}{|c|}{$\begin{array}{l}\text { - Micro/Household }(1-4) \\
\text { Total } \\
\text { Net Income Range of USO (in a month) }\end{array}$}} \\
\hline & & \\
\hline & & \\
\hline - $\leq$ Rp. 50.000 .000 & 71 & 63.9 \\
\hline - $\quad$ Rp. $50.000 .000-$ Rp. 100.000 .000 & 19 & 17.1 \\
\hline - Rp. $100.000 .000-$ Rp. 150.000 .000 & 7 & 6.3 \\
\hline \multirow{2}{*}{$\begin{array}{l}\text { - } \quad \text { Rp. } 150.000 .000 \\
\text { Total }\end{array}$} & 14 & 12.6 \\
\hline & 111 & 100 \\
\hline
\end{tabular}

Source: Survey Data, analyzed

\section{Validity}

Based on the EFA ${ }^{2}$, the result of the KaiserMeyer-Olkin (KMO) and Bartlett's test for the determining factors of USO survivability measurements were 0.79 with $p=0.000$. This result meant that the tested items were feasible for each measured construct. In addition, these results indicated the items successfully met the

\footnotetext{
${ }^{2}$ The EFA test were done in two phases, since, in the first phase, there is one measurement item (DP1) that reported below the standard of factor loading $(<0,50)$ and need to be dropped.
}

standards of sample size fulfillment (Hair, Black, Babin \& Anderson, 2014). From the 40 valid measurement items for the determining factors, it also reported that the overall item consistently forms ten factor components (see Appendix 1). Thus, it can be concluded that there were ten potential determining factors that can proceed to the next MRA test.

Based on the EFA, the ten potential determining factors of the USO were: 1) Human resources' reputation; 2) product innovation; 3) export activity; 4) business incubator; 5) 
business models' innovation; 6) business planning; 7) business orientation; 8) government support; 9) social network; and 10) capital access. The percentage of the total diversity reached its optimum value after rotation, where the ten factors reported the $R$-square as equal to 76.68 percent, with each eigenvalue $>1$.

Next, the result of the KMO and Bartlett's test for the survivability variable were 0.75 with $p=0.000$, indicating that the dependent variable was feasible for the measured construct and the existing measurement items successfully met the standards for sample size fulfillment (Hair et al., 2014). The factor loading of each survivability measurement items was $>0.5$ (see Appendix 2). Specifically, the EFA reported that the four items of the survivability measurement were consistently grouping in one factor component. In addition, the percentage of the total diversity of the survivability reached the optimum value after the extraction, where the survivability variable that formed was reported to have a high level of R-square (68.06 percent) with the eigenvalue $>1$.

\section{Reliability}

In this research, Cronbach's alpha was employed to test the reliability of the constructs. The overall test of the measurement items used in this study reported that the constructs were reliable, where the Cronbach's alpha of each construct was $>0.60$. Table 3 shows in detail the results of the reliability test from the overall instruments of the constructs.

\section{Multicollinearity}

Since there were a lot of independent variables (10), a multicollinearity test was performed to ensure there was no high correlation between the 10 independent variables used. The regression model is free from multicollinearity if the level of tolerance and the Variance Inflation Factor (VIF) are $>0.10$ and $<10$. Based on the multicollinearity test's result, the overall variables showed good tolerance levels $(<0.10)$ and the VIF was $<10$ (see Table 4). Thus, it can be concluded that the regression model in this study did not suffer from any symptoms of multicollinearity.

Table 3. Reliability

\begin{tabular}{clccc}
\hline No. & \multicolumn{1}{c}{ Variables } & $\begin{array}{c}\text { Number } \\
\text { of Items }\end{array}$ & $\begin{array}{c}\text { Cronbach's } \\
\text { Alpha }\end{array}$ & Reliability \\
\hline 1 & Human Resource Reputation (RSDM) & 10 & 0.91 & Reliable \\
2 & Product Innovation (IP) & 6 & 0.93 & Reliable \\
3 & Export Activity (AE) & 4 & 0.94 & Reliable \\
4 & Business Incubators (IB) & 4 & 0.92 & Reliable \\
5 & Business Model Innovation (IMB) & 3 & 0.94 & Reliable \\
6 & Business Planning (PB) & 3 & 0.82 & Reliable \\
7 & Business Orientation (OB) & 3 & 0.79 & Reliable \\
8 & Governement Support (DP) & 2 & 0.70 & Reliable \\
9 & Social Network (JS) & 3 & 0.71 & Reliable \\
10 & Capital Access (AM) & 2 & 0.69 & Reliable \\
11 & Survivability (KHP) & 4 & 0.83 & Reliable \\
\hline
\end{tabular}

Source: Survey Data, analyzed 
Table 4. Multicollinearity

\begin{tabular}{lcc}
\hline \multicolumn{1}{c}{ Variables } & Tolerance & VIF \\
\hline Human Resource Reputation (RSDM) & 0.42 & 2.34 \\
Product Innovation (IP) & 0.55 & 1.81 \\
Export Activity (AE) & 0.80 & 1.24 \\
Business Incubators (IB) & 0.75 & 1.32 \\
Business Model Innovation (IMB) & 0.52 & 1.91 \\
Business Planning (PB) & 0.54 & 1.82 \\
Business Orientation (OB) & 0.72 & 1.39 \\
Government Support (DP) & 0.77 & 1.28 \\
Social Network (JS) & 0.60 & 1.64 \\
Capital Access (AM) & 0.64 & 1.56 \\
\hline
\end{tabular}

Source: Survey Data, analyzed

\section{The Determining Factors of USO Survivability}

Based on the results of the MRA (see Table 5), it was reported that from the ten factors tested, there were only two factors which had a direct effect on the USOs' survivability: The human resource reputation $(\beta=0.308, p=0.006)$ and social network $(\beta=0.232, p=0.012)$. Meanwhile, the other eight factors had a level of significance far above the tolerance limit ( 0.10 or 10 percent). It was concluded that from the ten factors, there were only two factors which were the determining factors for USO survivability.

Furthermore, from these two determining factors for USO survivability, human resources' reputation was found to have a greater effect than social networks. It can be seen from the coefficient level of the human resources' reputation that it was higher than the coefficient level of social network $(0.308>0.232)$. This finding showed that human resources' reputation was the main determining factor for USO survivability.

Table 5. The Determining Factors of USO Survivability

\begin{tabular}{lccc}
\hline \multicolumn{1}{c}{ Variables } & $\begin{array}{c}\text { Standardized } \\
\text { Coefficient }(\boldsymbol{\beta})\end{array}$ & t & Sig. \\
\hline Human Resource Reputation (RSDM) & 0.308 & 2.833 & 0.006 \\
$\quad$ Product Innovation (IP) & 0.084 & 0.881 & 0.381 \\
Export Activity (AE) & 0.011 & 0.138 & 0.890 \\
Business Incubators (IB) & 0.022 & 0.267 & 0.790 \\
Business Model Innovation (IMB) & 0.118 & 1.201 & 0.233 \\
Business Planning (PB) & 0.100 & 1.046 & 0.298 \\
Business Orientation (OB) & 0.057 & 0.677 & 0.500 \\
Government Support (DP) & -0.017 & -0.209 & 0.835 \\
Social Network (JS) & 0.232 & 2.552 & 0.012 \\
Capital Access (AM) & 0.043 & 0.480 & 0.632 \\
\hline adjusted R-square $=0.448$ & & & \\
F $=9.922$ & & & \\
p-value $=0.000$ & & & \\
\hline
\end{tabular}

Source: Survey Data, analyzed 
Although the results of the MRA showed that there were only two determining factors for USO survivability, the simultaneous test showed the $F$ level (9.922) to be higher than the level of the $F$ table (1.66), in accord with the high level of significance $(p=0.000)$. These results indicated that the independent variables simultaneously influenced the USOs' survivability. In addition, the level of the adjusted $R$ square were reported to be 0.448 , which means the percentage of all the independent variables explaining the USOs' survivability was 44.8 percent. In other words, the ten factors have already proved quite extensively that they are the antecedents for USO survivability.

\section{Discussion}

In general, this study aims to identifying the determining factors for USO survivability in Indonesia. Based on the EFA, there were ten potential determining factors, i.e. 1) human resources' reputation; 2) product innovation; 3) export activity; 4) business incubators; 5) business models' innovation; 6) business planning; 7) business orientation; 8) government support; 9) social networks; and 10) capital access. However, after the MRA test, it was found that there were only two determining factors for USOs' survivability in Indonesia, namely human resources' reputation and social networks.

Furthermore, human resources' reputation was reported to be the main factor for the survivability of USOs in Indonesia, rather than social networks. These findings confirmed a number of empirical studies which emphasized the importance of a USO's reputation through the quality of its existing human resources (Pfeffer \& Salancik, 1978; Callan, 2001; Lee, 2001; Nutt, 2004; O'Shea et al., 2005; Lockett \&
Wright, 2005; Wright et al., 2005; BerbegalMirabent et al., 2015). Human resources' reputation has an important role for the USOs' survivability because it represents the firms' resources and capabilities to fulfill the expectations of all their stakeholders (Pfeffer \& Salancik, 1978), which normally results in an increase in their businesses' reputations. In line with the findings, Berbegal-Mirabent et al. (2015) in a similar study of university-based firms, also found that the quality of human resources was one of the main factors supporting their formation process.

In addition to the human resources' reputation, social networks were also found to be a determining factor in the USOs' survivability in Indonesia. In this study, social networks represent the ability of a USO to build a network, and the key personnel needed to obtain information and opportunities from,which are useful for the survival of the USO. This finding confirmed the argument of Huggins (2000) which suggests it is a matter of some urgency to involve the social networks of the entrepreneurs and the USO in order for it to survive. In addition, these findings also provided empirical evidence that social networks were not only important for the growth and success of a company (Elfring \& Hulsink, 2003; Kristiansen, 2003), but also for the survivability of the USOs, especially in Indonesia.

Finally, these findings provided empirical evidence about the factors required to increase the USOs' survivability in Indonesia. In this case, there were generally two determining factors, namely human resources' reputation and social networks. Specifically, the reputation of the USOs' human resources was considered to be the main factor in the USOs' survivability in Indonesia. 


\section{CONCLUSION}

The results of this study provide empirical evidence related to the determining factors of USO survivability in Indonesia. In this case, it was found that human resources' reputation was the main determining factor for the USOs' survivability in Indonesia. These findings indicated that to enhance the survivability of USOs in Indonesia, their management need to pay attention to improving the quality of their businesses' reputations; specifically through the ability of their human resources to meet the expectations of all their stakeholders (Pfeffer \& Salancik, 1978).

In addition, the findings also reinforce a number of previous empirical studies (Pfeffer \& Salancik, 1978; Callan, 2001; Lee, 2001; Nutt, 2004; O'Shea et al., 2005; Lockett \& Wright, 2005; Wright et al., 2005; Berbegal-Mirabent et al., 2015) which emphasized the importance of the reputation of a USO through the quality of its existing human resources. Accordingly, it provided new empirical evidence related to the importance of human resources' reputation in order to increase the survivability of USOs in Indonesia.

Another determining factor for the USOs' survivability was social networks. Although social networks were not the main determining factor, the study also found that social networks played an important role in the USOs' survivability in Indonesia. These findings indicated the need for urgency in involving the social networks of the firms and their key personnel to increase the USOs' survivability. In addition, these findings also confirm a number of previous empirical studies that suggested social networks have an important role in the survival of firms (Huggins, 2000; Elfring \& Hulsink, 2003; Kristiansen, 2003), especially for university-based firms. Further research sugges- tions from Grandi and Grimaldi (2003) were also answered in these findings.

The findings of this study provide important contributions, both theoretically and practically, to organizational survival studies, especially in the context of university-based firms in Indonesia. This study provides theoretical contributions by proving and reinforcing the RBT (Barney, 1991) in explaining the importance of the internal aspects of firms for their survivability. Based on the findings, both of the determining factors for a USO's survivability come from the internal aspects of the firm, even though this study also tested a number of external factors through the perspective of the contingency theory (Woodward, 1965, Burns \& Stalker, 1968, Lawrence \& Lorsch, 1969), as a complementary theory to the RBT. Moreover, this study also provides evidence about the ways to increase the USOs' survivability in Indonesia, which are by strengthening their human resources' reputations and utilizing the social networks of the USOs.

Based on these findings, human resources' reputation was the main determining factor for USOs' survivability in Indonesia. This shows that, in the USOs' activities, the role of their human resources' reputation is crucial in maintaining their existence. Therefore, the findings of this research encourage the USOs' practicioners to ensure the high quality of their human resources along with their positive reputations.

The practical contribution to the USOs, especially in Indonesia, is the USOs need to pay more attention to improving their businesses' reputations, through the quality of their human resources, to fulfill the expectations of their stakeholders (Pfeffer \& Salancik, 1978). The focus is not solely on developing the quality of their existing human resources, but also in terms of recruiting the required human resources. 
Specifically, USOs needs to recruit, develop, and retain the human resources who possess skills, specializations, creativity, intelligence, and global insight, as well as searching for those considered to be the best in the business.

\section{LIMITATION AND SUGGESTION}

Apart from the various contribution of the study, this study has several limitations to be following up on in any future research. First, in Indonesia, the USO is a relatively new research area, implying there is still a lack of relevant literature to help understand USOs in Indonesia (Payumo et al., 2014). Therefore, this study provides an initial understanding and empirical evidence about USOs in Indonesia, specifically by identifying the determining factors for their survival. Although there were a lot of analyzed variables, this study could not provide an illustration of the more complex relationships among the variables, since each of the variables was directly tested for its relationship with the USOs' survivability. In the causal relationship among the variables, there may be some variables that can be treated as mediators or moderators, to provide a more dynamic understanding. Therefore, future research needs to explore and discuss further the causal relationships of the relevant variables in understanding the USOs' survivability.

Second, in this study, the theoretical framework used in composing the USOs' survivability is still very common, and based only on the classification of the internal and external factors of the firms (the USOs). Although it gave considerable understanding of the USOs' survivability in general, this may not be able to give a deeper understanding about the issue. For example, this study found that human resources' reputation is the main determining factor for USO survivability in Indonesia. However, this study was unable to give the concrete form of human resources' reputation that is required for the USOs' survivability. Therefore, future research may be able to build a more specific theoretical framework to provide clear understanding about USOs.

Third, this study did not consider the differences in USOs' typology in Indonesia when constructing the important issue, since the relevant literature is so limited (Payumo et al., 2014); even though a USO needs to be seen as a firm that has different characteristics to other firms in general. As a university-based firm, and its core business being based on the intellectual property of the university, there are a number of university contexts that should be considered. Thus, future research needs to set up a particular study of USOs that focuses on capturing and classifying the various typologies of USOs, especially in Inodnesia.

\section{REFERENCES}

Aldrich, H. (1979). Organizations and environments. Englewood Cliffs, NJ: Prentice-Hall.

Aldrich, H., Zimmer, C. (1986). Entrepreneurship through social network, In D. L. Sexton \& R. W. Smilor (Ed.), The Art and Science Entrepreneurship (ed., 3-25). Cambridge: Ballinger Publishing.

Aldridge, T., Audretsch, D.B. (2011). The bayhdole act and scientist entrepreneurship. Research Policy, 40(8), 1058-1067.

Aldridge, T., Audretsch, D.B. (2010). Does policy influence the commercialization route?. Evidence from national institutes of health funded scientists. Research Policy, 39(5), 583-588.

Amit, R., and Schoemaker, P. J. (1993). Strategic assets and organizational rent. Strategic Management Journal, 14(1), 3346.

Association of University Technology Managers (AUTM). (2014). AUTM's Licensing Acitivity Survey. 
Association of University Technology Managers (AUTM). (2001). AUTM's Licensing Acitivity Survey.

Aspelund, A., Berg-Utby, T., and Skejevdal, R. (2005). Initial resources' influence on new venture survival: A longitudinal study of new technology-based firms. Technovation, 25, 1337-1347.

Barney, J. B. (2007). Gaining and sustaining competitive advantage $\left(3^{\text {rd }}\right.$ ed). New Jersey: Pearson Education.

Barney, J. B. (1995). Looking inside for competitive advantage. Academy of Management Executive, 9(4), 49-61.

Barney, J. B. (1991). Firm resources and sustained competitive advantage. Journal of Management, 17(1), 99-120.

Berbegal-Mirabent, J., Ribeiro-Soriano, D. E., and García, J. L. S. (2015). Can a magic recipe foster university spin-off creation?. Journal of Business Research, 68(11), 22722278.

Bernard, A. B., Eaton, J., Jensen, J. B., and Kortum, S. (2003). Plants and productivity in international trade. American Economic Review, 93(4), 1268- 1290.

Bonn, I. (2000). Staying on top: Characteristics of long-term survival. Journal of Organizational Change Management, 13(1), 32-48.

Bontis, N. (1998). Intellectual capital: An exploratory study that develops measures and models. Management Decision, 36(2), 63-76.

Botelho, A. J. J., and Almeida, M. (2011). Overcoming institutional shortcomings for academic spin-off policies in Brazil. International Journal of Technology Management \& Sustainable Development, 9(3), 175-193.

Burns, T., Stalker, G. W. (1968). The management of innovation. Chicago III: Quadrangle Books.

Calia, R. C., Guerrini, F. B., and Moura, G. L. (2007). Innovation network: From techno- logical development to business model reconfiguration. Technovation, 27(8), 426432.

Callan, B. (2001). Generating spin-off: Evidence from across the OECD. Science Technology Industry Review, (26), 13-55.

Caves, R. E. (1998). Industrial organization and new findings on the turnover and mobility of firms. Journal of Economic Literature, 36(4), 1947-1982.

Cefis, E., and Marsili, O. (2006). Survivor: The role of innovation in firms' survival. Research Policy, 35(5), 626-641.

Cooper, D. R., and Schindler, P. S. (2014). Business research methods $\left(12^{\text {th }}\right.$ ed). New York, NY: Irwin/McGraw-Hill.

Covin, J. G., and Slevin, D. P. (1989). Strategic management of small firms in hostile and benign environments. Strategic Management Journal, 10(1), 75-87.

Donaldson, L. (1995). American anti-management theories of organization: A critique of paradigm proliferation. Great Britain: Cambridge University Press.

Dzhumashev, R., Mishra, V., and Smyth, R. (2016). Exporting, R\&D investment and firm survival in the indian it sector. Journal of Asian Economics, 42, 1-19.

Elfring, T., and Hulsink, W. (2003). Network in entrepreneurship: The case of hightechnology firms. Small Business Economics, 21(4), 409-422.

Esteve-Pérez, S., and Mañez-Castillejo, J. A. (2008). The resource-based theory of the firm and firm survival. Small Business Economics, 30(3), 231-249.

Franklin, S., Lockett, A., and Wright, M. (2001). Academic and surrogate entrepreneurs and university spin-out companies. Journal of Technology Transfer, 26(1-2), 127-141.

Furlan, A., and Grandinetti, R. (2014). Spin-off performance in the start-up phase-a conceptual framework. Journal of Small Business and Enterprise Development, 21(3), 528-544. 
Gersick, C. J. G. (1991). Revolutionary change theories: A multilevel exploration of the punctuated change paradigm. Academy of Management Review, 16(1), 10-36.

Gilsing, V. A., Van Burg, E., and Romme, A. G. L. (2010). Policy principles for the creation and success of corporate and academic spinoffs. Technovation, 30(1), 12-23.

Goyal, P., and Yadav, V. (2014). To be or not to be a woman entrepreneur in a developing country?. Psychosociological Issues in Human Resource Management, 2(2), 68-78.

Grandi, A., and Grimaldi, R. (2003). Exploring the networking characteristics of new venture founding teams: A study of italian academic spin-off. Small Business Economics, 21(4), 329-341.

Grant, R. M. (1999). A resource-based theory of competitive advantage: Implications for strategy formulation. California Management Review, 33(3), 3-23.

Greenway, D., Kneller, R. (2007). Firm heterogeneity, exporting and foreign direct investment. Economic Journal, 117(517), F134-F161.

Gübeli, M. H., and Doloreux, D. (2005). An empirical study of university spin-off development. European Journal of Innovation Management, 8(3), 269-282.

Gudono. (2014). Teori organisasi (Edisi Ketiga). Yogyakarta: Badan Penerbit Fakultas Ekonomi Universitas Gadjah Mada.

Hair, J. F., Black, W. C., Babin, B. J., and Anderson, R. E. (2014). Multivariate data analysis $\left(7^{\text {th }}\right.$ ed). New Jersey: Pearson.

Hakala, H. (2013). Entrepreneurial and learning orientation: Effects on growth and profitability in the software sector. Baltic Journal of Management, 8(1), 102-118.

Hannan, M. T., and Freeman, J. H. (1989). Organizational ecology. Harvard University Press, Cambridge, MA.

Hannan, M. T., and Freeman, J. H. (1977). The population ecology of organizations.
American Journal of Sociology, 82(5), 929964.

Huang, H., Lai, M., and Lin, T. (2011). Aligning intangible assets to innovation in biopharmaceutical industry. Expert System with Applications, 38(4), 3827-3834.

Huggins, R. (2000). The success and failure of policy-implanted inter-firm network initiatives: Motivations, processes and structure. Entrepreneurship \& Regional Development, 12(2), 111-135.

Indarti, N., and Postma, T. (2013). Effect of network on product innovation: Empirical evidence from Indonesian SMEs, Journal of Innovation Management, 2, 140-158.

Indarti, N., and Langenberg, M. (2004). Factors affecting business success among SMEs: Empirical evidences from Indonesia. Second bi-annual European Summer University, 19.

Jarvis, C. (1990). The use of contengency management and motivational skill. Cambridge, MA: Educators Publishing Service.

Jambulingam, T., Kathuria, R., and Doucette, W. R. (2005). Entrepreneurial orientation as a basis for classification within a service industry: The case of retail pharmacy industry. Journal of Operations Management, 23, 23-42.

Kimura, F., and Kiyota, K. (2006). Export, FDI and productivity: Dynamic evidence from Japanese firms. Welwirtschaftliches Archiv/Review of World Economics, 142(4), 695-719.

Kristiansen, S. (2003). Social network and business success: The role of sub-cultures in an African context. American Journal of Economics and Sociology, 63(5), 11491171.

Kroll, H., and Liefner, I. (2008). Spin-off enterprises as a means of technology commercialisation in a transforming economy-evidence from three universities in China. Technovation, 28(5), 298-313.

Lawrence, P., and Lorsch, J. (1969). Organization and environment: Managing 
differentiation and integration. Homewood, III: Irwin-Dorsey.

Lawson, B., and Samson, D. (2001). Developing innovation capability in organizations: A dynamic capabilities approach. International Journal of Innovation Management, 5(3), 377-400.

Lee, G. (2001). Towards a contingent model of key staff retention: The new psychological contract reconsidered. South African Journal of Business Management, 32(1), 19.

Li, D., and Liu, J. (2014). Dynamic capabilities, environmental dynamism, and competitive advantage: Evidence from China. Journal of Business Research, 67(1), 2793-2799.

Lockett, A., Siegel, D., Wright, M., and Ensley, M. D. (2005). The creation of spin-off firms at public research institutions: Managerial and policy implications. Research Policy, 34(7), 981-993.

Lockett, A., and Wright, M. (2005). Resources, capabilities, risk capital and the creation of university spin-out companies. Research Policy, 34(7), 1043-1057.

Löfsten, H. (2010). Critical incubator dimensions for small firm performance $-\mathrm{a}$ study of new technology-based firms localized in 16 incubators. International Journal of Business Innovation and Research, 4(3), 256-279.

Löfsten, H., Lindelöf, P. (2002). Science parks and the growth of new technology based firms-academic-industry links, innovation and markets. Research Policy, 3(6), 859876.

Löfsten, H. (2016). Business and innovation resources: Determinant for the survival of new technology-based firms. Management Decision, 54(1), 88-106.

Mas-Verdú, F., Ribeiro-Soriano, D., and RoigTierno, N. (2015). Firm survival: The role of incubators and business characteristics. Journal of Business Research, 68(4), 793796.
McMahon, R. G. (2001). Growth and performance of manufacturing SMEs: The influence of financial management characteristics. International Small Business Journal, 19(3), 10-28.

Melitz, M. (2003). The impact of trade on aggregate industry productivity and intraindustry reallocations. Econometrica, 71(6), 1695-1725.

Miller, D. (1983). The correlates of entrepreneurship in three types of firms. Management Science, 29(7), 770-790.

Naidoo, V. (2010). Firm survival through a crisis: The influence of market orientation, marketing innovation and business strategy. Industrial Marketing Management, 39(8), 1311-1320.

Nelson, R. R., and Winter, S. G. (1985). An evolutionary theory of economic change. Hardvard, MA: Harvard University Press.

Nerkar, A., and Shane, S. (2003). When do startups that exploit patented academic knowledge survive?. International Journal of Industrial Organization, 21(9), 13911410.

Nicolò, D. (2015). Towards a theory on corporate reputation and survival of young firms. Procedia Economics and Finance, 22, 296-303.

Nutt, P. C. (2004). Organizational development. Journal of Management Studies, 41(7), 1083-1103.

O'Shea, Rory P., Chugh, Harveen, Allen, and Thomas J. (2008). Determinant and consequences of university spin-off activity: A conceptual framework. Journal of Technology Transfer, 33(6), 635-666.

O'Shea, R. P., Allen, T., Chevalier, A., and Roche, F. (2005). Entrepreneurial orientation, technology transfer and spin-off performance of U.S. Universities. Research Policy, 34(5), 994-1009.

Parry, S., Jones, R., Rowley, J., and KupiecTeahan, B. (2012). Marketing for survival: A comparative case study of SME software 
firms. Journal of Small Business and Enterprise Development, 19(4), 712-728.

Payumo, J. G., Arasu, P., Fauzi, A. M., Siregar, I. Z., and Noviana, D. (2014). An entrepreneurial, research-based university model focused on intellectual property management for economic development in emerging economies: The case of Bogor Agricultural University, Indonesia. World Patent Information, 36, 22-31.

Penrose, E. T. (1959). The theory of the growth of the firm. New York: John Wiley \& Sons.

Perez, S. E., LLopis, A. S., and LLops, J. A. S. (2004). The determinant of survival of Spanish manufacturing firms. Review of Industrial Organization, 25(3), 251-273.

Peters, L., Rice, M., and Sundararajan, M. (2004). The role of incubators in the entrepreneurial process. The Journal of Technology Transfer, 29(1), 83-91.

Pfeffer, J., and Salancik, G. R. (1978). The external control of organization: A resource dependence perspective, New York: Harper and Row.

Pirnay, F., Surlemont, B., and Nlemvo, F. (2003). Toward a typology of university spin-offs. Small Business Economics, 21(4), 355-369.

Rasmussen, E. (2011). Understanding academic entrepreneurship: Exploring the emergence of university spin-off ventures using process theories. International Small Business Journal, 29(5), 448-471.

Ricardo, D. (1817). On the principles of political economy and taxation ( $1^{\text {st }}$ ed.). London: John Murray.

Schwartz, M. (2009). Beyond incubation: An analysis of firm survival and exit dynamics in the post-graduation period. The Journal of Technology Transfer, 34(4), 403-421.

Schwartz, M. (2013). A control group study of incubators impact to promote firm survival, Journal of Technology Transfer, 38(3), 302331.
Scott, R. W. (2001). Institutions and organization $\left(2^{\text {nd }}\right.$ ed). Thousand Oaks, CA: Sage.

Scott, R. W. (1998). Organizations: rational, natural, and open system ( $4^{\text {th }}$ ed). Upper Saddle River, New Jersey: Prentice Hall.

Selznick, P. (1957). Leadership in administration. New York, NY: Harper and Row.

Shane, S., and Cable, D. (2002). Network ties, reputation, and the financing of new ventures. Management Science, 48(3), 364381.

Smith, H. L., Chapman, D., Wood, P., Barnes, T., and Romeo, S. (2014). Entrepreneurial academics and regional innovation system: The case of spin-offs from London's universities. Environment and Planning $C$ : Government and Policy, 32(2), 341-359.

So, A. D., Sampat, B. N., Rai, A. K., CookDeegan, R., Reichman, J. H., Weissman, R., and Kapczynski, A. (2008). Is Bayh-Dole good for developing countries?. Lessons from the US experience. PLoS biology, 6 (10), e262.

Sørheim, R., Widding, L.Ø., Oust, M., and Madsen, Ø. (2011). Funding of university spin-off companies: A conceptual approach to financing challenges. Journal of Small Business and Enterprise Development, 18(1), 58-73.

Stafford, K., Bhargava, V., Danes, S. M., Haynes, G., \& Brewton, K. E. (2010). Factors associated with long-term survival of family businesses: Duration analysis. Journal of Family and Economic Issues, 31(4), 442-457.

Subramaniam, M., and Youndt, M. A. (2005). The influence of intellectual capital on the types of innovative capabilities. Academy of Management Journal, 48(3), 450-463.

Taylor, F. W. (1911). Principles of scientific management. New York: Harper and Row.

Thakur, R., and Hale, D. (2013). Service innovation: A comparative study of U.S. 
and Indian service firm. Journal of Business Research, 66(8), 1108-1123.

Tsai, W. (2001). Knowledge transfer in intraorganizational networks: Effects of network position and absorptive capacity on business unit innovation and performance. Academy of Management Journal, 44(5), 996-1004.

Vidal, E., and Mitchell, W. (2013). When do first entrants become first survivors?. Long Range Plan, 46(4-5), 335-347.

Velu, C. (2015). Business model innovation and third-party alliance on the survival of new firms. Technovation, 35, 1-11.

Velu, C., and Stiles, P. (2013). Managing decision-making and cannibalization for parallel business model. Long Range Plan, 46, 443-458.

Walter, L. A., Edelman, L. F., and Hatten, K. J. (2014). The US brewing industry, strategic windows and survival. Journal of Management History, 20(4), 434-358.

Watson, T. (2007). Reputation and ethical behavior in a crisis: Predicting survival. Journal of Communication Management, 11(4), 371-384.

Weiss, A. M., Anderson, E., and MacInnis, D. J. (1999). Reputation management as motivation for sales structure decisions. Journal of Marketing, 63(4), 74-89.
Wernerfelt, B. (1984). A resource-based view of the firm. Strategic Management Journal, 5(2), 171-180.

Wiggins, J., and Gibson, D. V. (2003). Overview of US incubators and the case of the Austin technology incubator. International Journal of Entrepreneurship and Innovation Management, 3(3), 56-66.

Woodward, J. (1965). Industrial Organization: Theory and Practice. London: Oxford University Press.

Wright, M., Lockett, A., Clarysse, B., and Binks, M. (2006). University spin-out company and venture capital. Research Policy, 35(4), 481-501.

Wright, M., Binks, M., Lockett, A., and Clarysse, B. (2005). University spin-out company and venture capital. Research Policy, 35, 481-501.

Youndt, M. A., Snell, S. A. (2004). Human resource configurations, intellectual capital, and organizational performance. Journal of Management Issues, 16(3), 337-360.

Zott, C., and Amit, R. (2008). The fit between product market strategy and business model: Implications for firm performance. Strategic Management Journal, 29(1), 1-6.

Zott, C., and Amit, R. (2001). Value creation in e-Business. Strategic Management Journal, 22, 493-520.

Notice: The Journal of Indonesian Economy and Business and its Board of Editors are not responsible for any errors or flaws found in this article. The authors take full responsibility for their work. 
APPENDIX 1

EFA of The Determining Factors

\begin{tabular}{|c|c|c|}
\hline Items & $\begin{array}{c}\text { Factor } \\
\text { Loading }\end{array}$ & $\begin{array}{c}\text { Factors } \\
\text { Numbers }\end{array}$ \\
\hline \multicolumn{3}{|c|}{ Human Resource Reputation (RSDM) } \\
\hline RSDM1 & 0.69 & \multirow{10}{*}{1} \\
\hline RSDM2 & 0.53 & \\
\hline RSDM3 & 0.60 & \\
\hline RSDM4 & 0.70 & \\
\hline RSDM5 & 0.62 & \\
\hline RSDM6 & 0.76 & \\
\hline RSDM7 & 0.67 & \\
\hline RSDM8 & 0.68 & \\
\hline RSDM9 & 0.76 & \\
\hline RSDM10 & 0.78 & \\
\hline \multicolumn{3}{|l|}{ Product Innovation (IP) } \\
\hline IP1 & 0.77 & \multirow{6}{*}{2} \\
\hline IP2 & 0.84 & \\
\hline IP3 & 0.85 & \\
\hline IP4 & 0.84 & \\
\hline IP5 & 0.72 & \\
\hline IP6 & 0.78 & \\
\hline \multicolumn{3}{|l|}{ Export Activity (AE) } \\
\hline AE1 & 0.91 & \multirow{4}{*}{3} \\
\hline AE2 & 0.91 & \\
\hline AE3 & 0.91 & \\
\hline AE4 & 0.88 & \\
\hline \multicolumn{3}{|l|}{ Business Incubators (IB) } \\
\hline IB1 & 0.89 & \multirow{4}{*}{4} \\
\hline IB2 & 0.92 & \\
\hline IB3 & 0.90 & \\
\hline IB4 & 0.73 & \\
\hline \multicolumn{3}{|c|}{ Business Model Innovation (IMB) } \\
\hline IMB1 & 0.83 & \multirow{3}{*}{5} \\
\hline IMB2 & 0.76 & \\
\hline IMB3 & 0.70 & \\
\hline \multicolumn{3}{|l|}{ Business Planning (PB) } \\
\hline PB1 & 0.88 & \multirow{3}{*}{6} \\
\hline PB2 & 0.79 & \\
\hline PB3 & 0.67 & \\
\hline \multicolumn{3}{|l|}{ Business Orientation (OB) } \\
\hline $\mathrm{OB} 1$ & 0.72 & \multirow{3}{*}{7} \\
\hline OB2 & 0.86 & \\
\hline OB3 & 0.73 & \\
\hline
\end{tabular}




\begin{tabular}{lll}
\hline Government Support (DP) & & 8 \\
DP2 & 0.88 & \\
DP3 & 0.70 & \\
Social Network (JS) & & 9 \\
JS1 & 0.55 & \\
JS2 & 0.61 & \\
JS3 & 0.85 & 10 \\
Capital Access (AM) & & \\
AM1 & 0.83 & \\
AM2 & 0.63 &
\end{tabular}

Source: Survey Data, analyzed

APPENDIX 2

EFA of The USO Survivability

\begin{tabular}{|c|c|c|}
\hline & Factor Loading & $\begin{array}{l}\text { Component } \\
\text { Factor }\end{array}$ \\
\hline \multicolumn{3}{|c|}{ USO Survivability } \\
\hline KHP1 & 0.86 & \multirow{4}{*}{1} \\
\hline KHP2 & 0.86 & \\
\hline KHP3 & 0.81 & \\
\hline KHP4 & 0.75 & \\
\hline
\end{tabular}

Source: Survey Data, analyzed 